\title{
Microbiological quality of water sources in the West region of Cameroon: quantitative detection of total coliforms using Micro Biological Survey method
}

Rodrigue Mabvouna Biguioh', Sali Ben Béchir Adogaye ${ }^{1 *}$ (D) Patrick Martial Nkamedjie Pete ${ }^{2}$, Martin Sanou Sobze ${ }^{3}$, Jean Blaise Kemogne ${ }^{4}$ and Vittorio Colizzi ${ }^{1}$

\begin{abstract}
Background: Adequate supply of safe drinking-water remains a critical issue in most developing countries. The whole western region of Cameroon doesn't have a sustainable continuous water supply system, which leads most people to use potentially contaminated water sources to meet their daily water needs. Previous, studies carried out in similar areas of Cameroon have highlighted the poor bacteriological quality of water sources used as drinkingwater by the local populations.

Methods: This study used the Micro Biological Survey method, a rapid colorimetric test for the quantitative detection of Coliforms in water samples. 22 water sources (12 improved and 10 unimproved) were identified; 1 water sample of $50 \mathrm{ml}$ was collected in sterile plastic tubes, immediately kept in a refrigerator box and transported to the laboratory for analysis. $1 \mathrm{ml}$ of each sample was inoculated in the Coliforms Micro Biological Survey (Coli MBS) vials initially rehydrated with $10 \mathrm{ml}$ of sterile distilled water. The Coli MBS vials were closed, shaken for about $30 \mathrm{~s}$ for homogenization and then incubated at $37^{\circ} \mathrm{C}$. From the initial red color of the Coli MBS vials, changes in color of the reaction vials were monitored at three different time intervals (12 h, $19 \mathrm{~h}$ and $24 \mathrm{~h}$ ), corresponding to three levels of contamination.

Results: The average distance $(8.7 \mathrm{~m})$ of the latrines from the nearest water source was less than the minimal recommended distance $(15 \mathrm{~m})$ to ovoid external contamination. The $\mathrm{pH}$ of water samples ranged from 5.5 to 8.3 and the maximum temperature found $\left(26^{\circ} \mathrm{C}\right)$ was almost at level favorable to outbreaks of waterborne diseases such as cholera. The presence of Total Coliforms was detected in $90.91 \%$ of the samples. $40 \%$ of samples were positive $12 \mathrm{~h}$ after the analysis beginning. High level of contamination was observed in unimproved water sources, $50 \%$ after $12 \mathrm{~h}$ corresponding to Total Coliforms concentration of $10<x<103 \mathrm{CFU} / \mathrm{ml}$ and the other samples after $19 \mathrm{~h}$ (Total Coliforms concentration: $1<\mathrm{x}<10 \mathrm{CFU} / \mathrm{ml}$ ).

(Continued on next page)
\end{abstract}

*Correspondence: benbechir_sali@yahoo.fr

${ }^{1}$ Faculty of Medicine and surgery, University of Roma "Tor Vergata", Rome, Italy

Full list of author information is available at the end of the article

(c) The Author(s). 2020 Open Access This article is licensed under a Creative Commons Attribution 4.0 International License, which permits use, sharing, adaptation, distribution and reproduction in any medium or format, as long as you give appropriate credit to the original author(s) and the source, provide a link to the Creative Commons licence, and indicate if changes were made. The images or other third party material in this article are included in the article's Creative Commons licence, unless indicated otherwise in a credit line to the material. If material is not included in the article's Creative Commons licence and your intended use is not permitted by statutory regulation or exceeds the permitted use, you will need to obtain permission directly from the copyright holder. To view a copy of this licence, visit http://creativecommons.org/licenses/by/4.0/. The Creative Commons Public Domain Dedication waiver (http://creativecommons.org/publicdomain/zero/1.0/) applies to the data made available in this article, unless otherwise stated in a credit line to the data. 
(Continued from previous page)

Conclusion: This study revealed the poor microbiological quality of water used by local populations of our study

sites. There is need to conduct further qualitative microbiology studies to isolate potential germs involved in

outcome of diarrheal diseases.

Keywords: Micro biological survey, Water microbiological analysis, MBS-HACCP \& water easy test ${ }^{\circledR}$, Water points, West Cameroon,

\section{Background}

Safe drinking-water is an essential resource for human life, a basic human right and one of the key components of effective health protection policy [1, 2]. It is known that drinking-water is one of the main transmission pathways for diarrheal diseases [2]. It is also established that improving the bacteriological quality of drinkingwater significantly reduces the risk of waterborne diseases [3]. Thus, every effort should be made to achieve a satisfactory drinking-water supply to all in terms of adequacy, safety and accessibility [2].

Most developing countries face high population growth which poses a considerable challenge for local authorities who are not able to meet basic needs of populations whose most crucial problem is sustainable access to save drinking-water [2, 3]. Ensuring availability and sustainable management of water sources and sanitation for all, remains one of the most important Sustainable Development Goals governments need to achieve [4]. According to the World Health Organization (WHO), safe drinking-water does not represent any significant risk to health over a lifetime of consumption, including different sensitivities that may occur between life stages [2]. Therefore, microbial, chemical and other acceptability aspects of drinking-water should feet with WHO guidelines for drinking-water quality [2].

Supply of safe drinking-water for human is a critical problem in African countries [5-7], more importantly in remote areas due to the hyper centralization of public management services $[8,9]$. As in other parts of the country, but less in the Central or Littoral regions, the West Cameroon does not have a continuous water supply system, leading to majority of people to use surface, well, borehole and river water as alternative source of drinking-water and for other water needs $[8,10]$. Studies carried out in similar areas of Cameroon have highlighted the poor bacteriological quality of these water sources [11-14].

Waterborne diseases are the second leading cause of death and infant morbidity after malaria in Bafoussam and in other main cities of the West Cameroon [15], indicating the non-achievement of bacteriological standards of drinking-water standards for human consumption [16]. Morbidity and mortality rates of diarrheal diseases are more prevalent among children under 5 [15]. Among the top 10 diseases in children under 5 including malaria, infection of the lower respiratory tract, upper respiratory tract infection, meningitis, typhoid fever, bloody diarrhea, diarrhea (non-bloody diarrhea), dysentery, parasitic worm infection and gastritis, 4 of them are related to the consumption of unsafe water and/or food $[15,16]$. The germs responsible for these diseases are generally transmitted by feco-oral route and represent a major concern in public health risk [16]. Microbiological contamination of water occurs in a context of poor waste management including faeces [17]. Contaminated water with bacteria should not be intended for human consumption. Coliforms can be used as indicator to monitor the microbiological quality of drinking-water [18, 19] and their rapid detection is therefore crucial and should be easy to perform in order to evaluate water quality especially in resource limited countries, such as Cameroon. Preventive public health approaches for safe drinking-water must include rapid assessment of microbiological quality of water to guide monitoring of water quality and treatment. In line with this point of view, this study aimed to assess the potability of water points using Micro Biological Survey Hazard Analysis Critical Control Point (MBS-HACCP) \& water Easy test ${ }^{\oplus}[20]$ in the West Cameroon.

\section{Methods \\ Study area and sampling}

The study was performed in West region of Cameroon (Fig. 1), an area of $14,000 \mathrm{~km}^{2}$ located in the centralwestern part of the country with a total population estimated at 1,921,590 inhabitants [21]. Even if the region is the smallest of the country in terms of area, the West region has the highest population density $\left(140 / \mathrm{km}^{2}\right)$. The climate is mainly cold with an average temperature varying between 15 and $22^{\circ} \mathrm{C}$, sometimes reaches $30^{\circ} \mathrm{C}$ during the dry season and rainfall is moderate.

A water source was considered as improved if the nature of its construction satisfactorily protects the water from any external contamination, especially faeces. 12 improved and 10 unimproved water sources were identified in the study area, especially in the localities of Bafoussam $1^{\mathrm{er}}$, Bafoussam $2^{\mathrm{e}}$, Foumbot, Galim and Kouoptamo (Table 1). At each site, 1 water sample of 


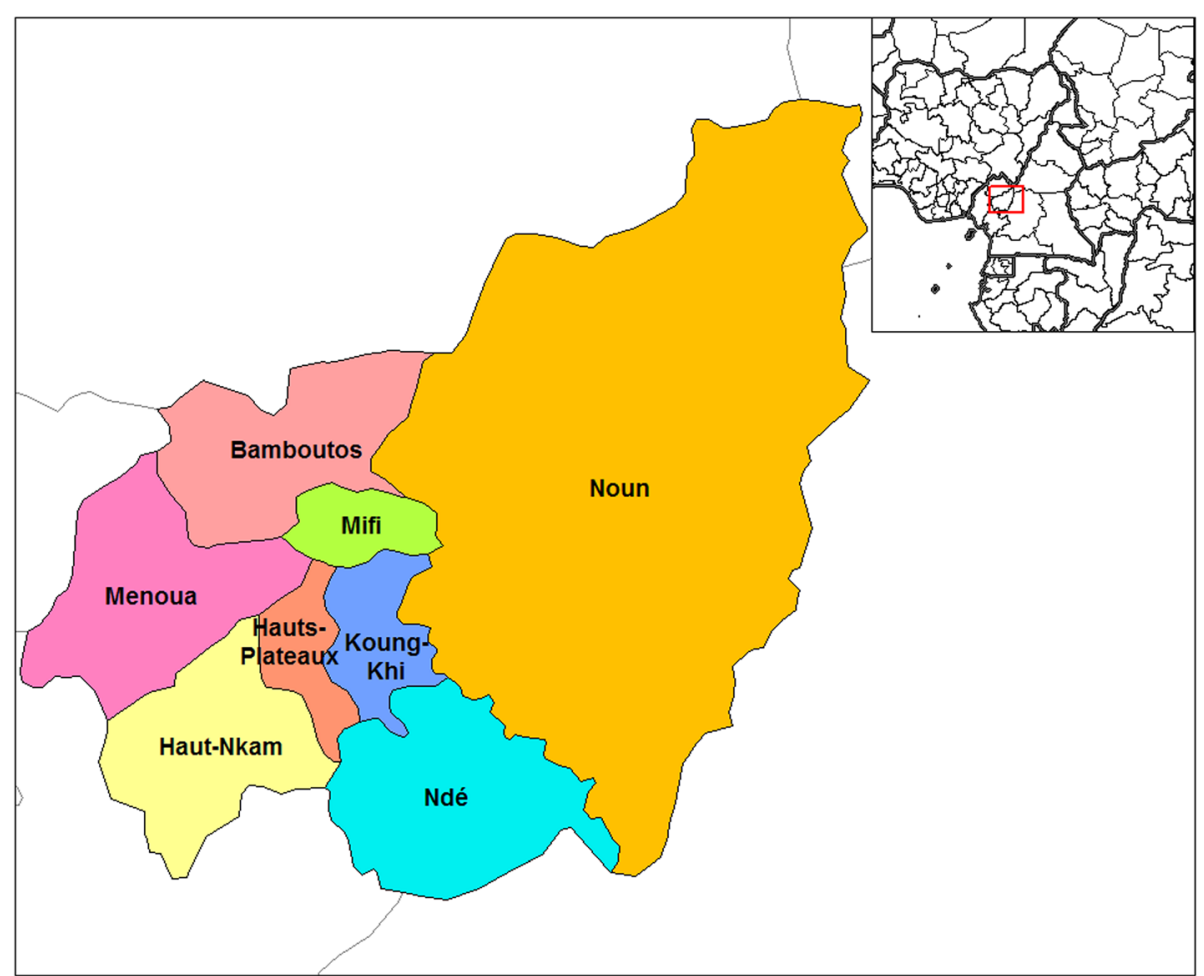

Fig. 1 Map of the Western Region of Cameroon. Source: Wikimedia

Commons. https://commons.wikimedia.org/wiki/File:West_Cameroon_divisions.png

$50 \mathrm{ml}$ was collected in sterile plastic tubes and immediately kept in a refrigerator box and transported to the laboratory for microbiological analysis.

Water sources in this study were located on areas of public accessibility and are used for free by local population. The 12 improved sources were constructed by volunteers, but they don't have authority over these water points in terms of management and control. So, for the collection of water samples, no authorization was requested.

\section{MBS-HACCP, water easy test and MBS method}

The MBS-HACCP \& water Easy test is a rapid colorimetric test for the quantitative detection of coliforms in water samples [20]. The method is based on observation of color change of the suspension formed in the analysis vial following inoculation of the test sample. The color change occurs when the water sample added in the vial contains Coliform bacteria, the greater the amount of microorganisms, the more rapid the color change and thus, a positive result (contamination). The concentration of bacteria is expressed in Colony Forming Units $(\mathrm{CFU} / \mathrm{ml})$ for the analysis water samples. The MBS method is based on the detection of bacterial metabolism and not on the replication of microorganisms, but the results (in terms of number) correspond to individual bacterial cells.
Water analysis: MBS operating procedures for quantitative detection of Total coliforms

We followed the MBS standard protocol for quantitative detection of Total Coliforms [20]. Before starting with the analysis, the MBS vials were rehydrated with $10 \mathrm{ml}$ of sterile distilled water and shaken to dissolve the reagent. $1 \mathrm{ml}$ of each sample was collected from plastic tubes using a sterile Pasteur pipette and inoculated in the Coli MSB vial. The vials were then closed and shaken for about $30 \mathrm{~s}$ for homogenization. Each analysis was done twice, the vials were incubated at $37^{\circ} \mathrm{C}$. The color changes of the Coli reaction vials were monitored using the chromatic scale provided with the tests at three different time intervals $(12 \mathrm{~h}, 19 \mathrm{~h}$ and $24 \mathrm{~h}$ ), corresponding to three levels of contamination. The initial color of the Coli vials is red. A color change from red to yellow after $12 \mathrm{~h}$ indicates a very high contamination (Total Coliforms concentration $>10^{3} \mathrm{CFU} / \mathrm{ml}$ ), a color change at $19 \mathrm{~h}$ indicates a high contamination (Total Coliforms concentration $10<\mathrm{x}<10^{3} \mathrm{CFU} / \mathrm{ml}$ ) and a color change at $24 \mathrm{~h}$ corresponds to Total Coliforms concentration of $1<\mathrm{x}<10 \mathrm{CFU} / \mathrm{ml}[20]$.

\section{Results}

\section{Description of water points}

Water samples were collected in 22 sites. Improved water sources accounted for $54.55 \%(n=12)$ while $45.5 \%$ 
Table 1 Sampling location and type of water sources

\begin{tabular}{lll}
\hline Sampling location & Water sources & Sample collection date \\
\hline Bafoussam 1er & Unimproved water spring & $23 / 09 / 2018$ \\
& Unprotected well & $25 / 09 / 2018$ \\
& Public water drilling & $28 / 09 / 2018$ \\
Bafoussam 2e & Improved water spring & $24 / 09 / 2018$ \\
& Protected well & $28 / 09 / 2018$ \\
Foumbot & Improved water spring & $23 / 09 / 2018$ \\
& River & $24 / 09 / 2018$ \\
& Improved water spring & $24 / 09 / 2018$ \\
& Unprotected well & $24 / 09 / 2018$ \\
& Protected well & $24 / 09 / 2018$ \\
& Protected well & $24 / 09 / 2018$ \\
Kalim & Unprotected well & $24 / 09 / 2018$ \\
& Protected well & $23 / 09 / 2018$ \\
& Unprotected well & $23 / 09 / 2018$ \\
& Unprotected well & $25 / 09 / 2018$ \\
& Unprotected well & $25 / 09 / 2018$ \\
& Protected well & $25 / 09 / 2018$ \\
& Improved water spring & $28 / 09 / 2018$ \\
& Unprotected well & $28 / 09 / 2018$ \\
& Unproved water spring & $28 / 09 / 2018$ \\
& & $28 / 09 / 2018$ \\
& & $28 / 09 / 2018$ \\
\hline \multirow{3}{*}{ Koum } & \\
& & \\
& & \\
& &
\end{tabular}

$(n=10)$ were unimproved. The average distance of the latrines from the nearest water source was $8.7 \mathrm{~m}$. The closest and the farthest water sources were at 1 and 100 $\mathrm{m}$ respectively from the nearest latrine. The $\mathrm{pH}$ of the water samples collected ranged from 5.5 to 8.3 and the temperature varied from 22 to $26^{\circ} \mathrm{C}$. Most of water sources were clear $(90.91 \%)$ and the turbidity was noticed in both cases (Table 2).

\section{Total coliforms samples contamination}

Of the 22 water samples analyzed, 20 (90.91\%) contained Coliforms (Fig. 2). Both improved and unimproved water sources were evenly contaminated with Coliforms. All water samples with yellow coloration were positive as well as $90 \%$ of clear water samples. This result was similar for the turbidity.

\section{Total coliforms levels of contamination in water samples analyzed}

Of the 20 samples positive for Coliforms, $40 \%(n=8)$ were highly positive, indicating a very high level of coliforms contamination (Total Coliforms concentration > $10^{3} \mathrm{CFU} / \mathrm{ml}$ ). Of all positive samples, high level of contamination was observed in unimproved water sources, $50 \%$ at $12 \mathrm{~h}$ corresponding to Total Coliforms concentration of $10<\mathrm{x}<10^{3} \mathrm{CFU} / \mathrm{ml}$ and the other samples after $19 \mathrm{~h}$ (Total Coliforms concentration of $1<\mathrm{x}<10$ $\mathrm{CFU} / \mathrm{ml}$ ). Of all the water sources, only two samples (collected in improved water sources) were positives at $24 \mathrm{~h}$ (Total Coliforms concentration of $1<\mathrm{x}<10 \mathrm{CFU} /$ ml) (Table 3).

\section{Discussion}

Safe drinking water is essential for life. This study aimed at analyzing the presence of bacteria, through quantitative detection of Total Coliforms in both improved and unimproved water sources in the West region of Cameroon. Inhabitants of the study area are in majority poor with limited capacities including financial to afford pipe borne water $[8,15]$, they turn to health threatening and potentially highly polluted water sources which could explain why diarrheal diseases mostly occur in populations with limited financial means. This has been described by a study conducted in South Africa, which highlighted that cholera outbreak does not on results from inadequate sanitations, but also due to poverty [22].

According to the WHO guidelines for drinking-water quality, the microbial safety of drinking-water includes the prevention of the drinking-water contamination by the microorganisms or the reduction of contamination to levels not injurious to human health [2]. While ingestion of microorganisms from contaminated water and

Table 2 Summary of the water sources parameters

\begin{tabular}{|c|c|c|c|c|}
\hline & & \multicolumn{2}{|c|}{ Types of water sources } & \multirow[b]{2}{*}{ Overall } \\
\hline & & Improved & Unimproved & \\
\hline \multicolumn{2}{|l|}{ Average $\mathrm{pH}$} & $6.7 \pm 0.3$ & $6.2 \pm 0.7$ & $6.5 \pm 0.6$ \\
\hline \multicolumn{2}{|c|}{ Average temperature $\left({ }^{\circ} \mathrm{C}\right)$} & $23.2 \pm 0.6$ & $23.5 \pm 1$ & $23.3 \pm 0.8$ \\
\hline \multicolumn{2}{|c|}{ Average distance to nearest latrine (m) } & $5 \pm 2.7$ & $13.3 \pm 30$ & $8.7 \pm 20.5$ \\
\hline \multirow[t]{2}{*}{ Color of water } & Clear (\%) & $12(100)$ & $8(80)$ & $20(90.91)$ \\
\hline & Yellowish (\%) & 0 & $2(20)$ & $2(9.09)$ \\
\hline \multirow[t]{2}{*}{ Turbidity } & No (\%) & $12(100)$ & $8(80)$ & $20(90.91)$ \\
\hline & Yes (\%) & 0 & $2(20)$ & $2(9.09)$ \\
\hline
\end{tabular}




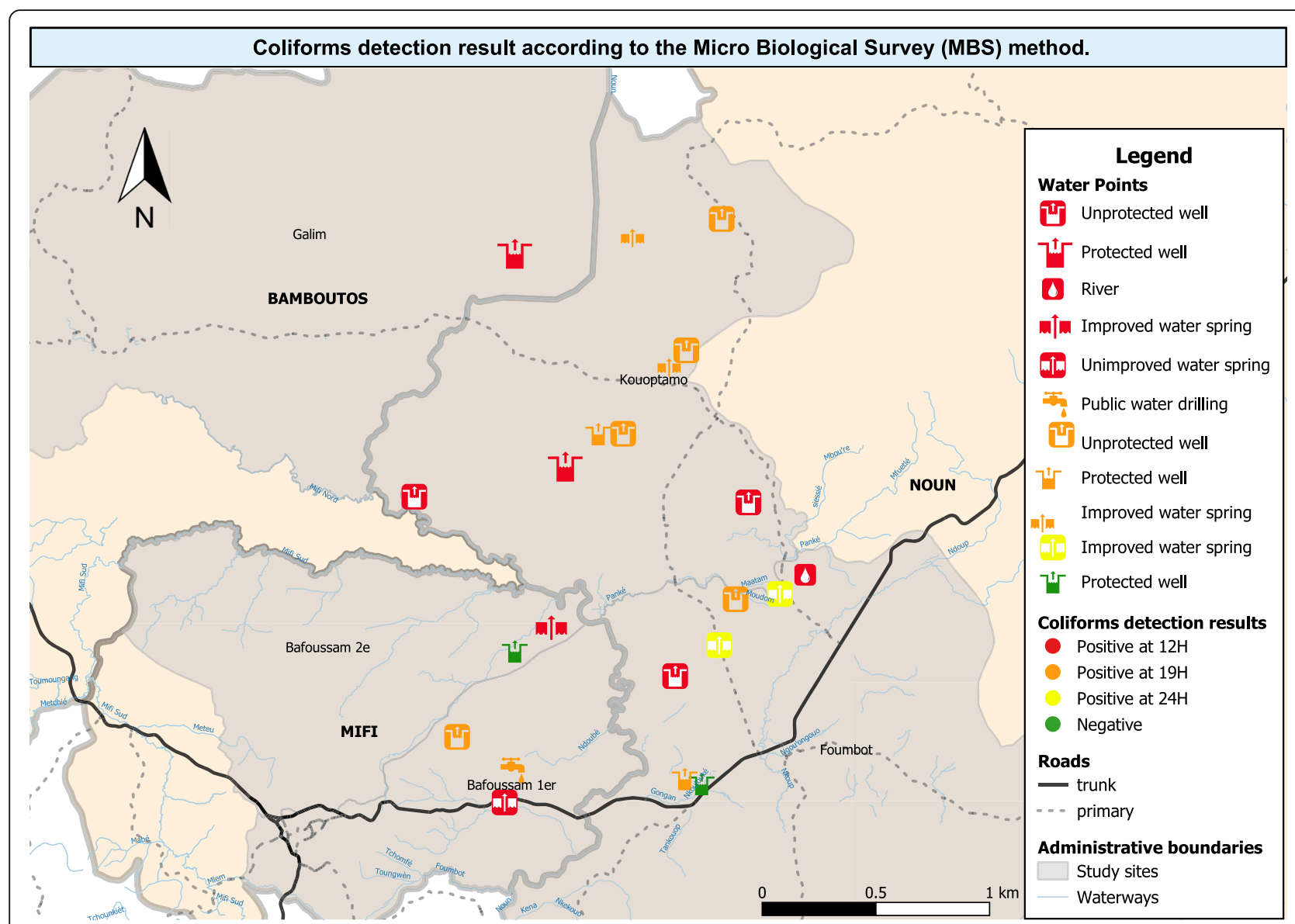

Fig. 2 Coliforms detection result according to the Microbiological Survey (MBS) method. Source: Authors. Generated by QGIS version 3.4.11Madeira (GNU GENERAL PUBLIC LICENSE Version 2, June 1991)

food is the main cause of diarrheal diseases [23], lack of safe drinking-water is one of the leading causes of death especially in children under $5[15,16]$. Total Coliforms are used as indicators of faecal pollution, the effectiveness of water filtration or disinfection, the integrity and cleanliness of water distribution systems [24, 25]. The WHO guideline for drinking-water quality recommends the absence of Total Coliforms in drinking-water [2]. This study highlights poor quality of the water due to the presence of Total Coliforms in high concentration. In fact, of the 22 water samples collected, 20 contained coliforms which could be associated with high risks of diarrheal diseases outbreaks, such as cholera as suggested by previous studies that stipulate fecal coliformcontaminated water may contain Vibrio Cholerae [26, 27]. Both types of water sources (improved and unimproved) were contaminated indicating a possible human or animal faecal pollution of these water points.

The minimal recommended distance between latrine and water source to avoid external contamination ranged between 15 and $50 \mathrm{~m}[2,28]$. The average distance found in this study did not feet with this recommendation. Even though improved water sources were more closely to latrines, unimproved water points which

Table 3 Summary of total Coliforms contamination results according to monitoring time points

\begin{tabular}{|c|c|c|c|c|c|c|}
\hline \multirow[b]{3}{*}{ Monitoring time points and Coliforms concentration } & \multicolumn{4}{|c|}{ Types of water sources } & & \\
\hline & \multicolumn{2}{|c|}{ Improved } & \multicolumn{2}{|c|}{ Unimproved } & \multicolumn{2}{|c|}{ Total } \\
\hline & $\bar{n}$ & $\%$ & $\mathrm{n}$ & $\%$ & $\mathrm{~N}$ & $\%$ \\
\hline $12 \mathrm{~h}\left(>10^{3} \mathrm{CFU} / \mathrm{ml}\right)$ & 3 & 30 & 5 & 50 & 8 & 40 \\
\hline $19 \mathrm{~h}\left(10<x<10^{3}\right.$ CFU/ml) & 5 & 50 & 5 & 50 & 10 & 50 \\
\hline $24 \mathrm{~h}(1<x<10 \mathrm{CFU} / \mathrm{ml})$ & 2 & 20 & 0 & 0 & 2 & 10 \\
\hline Total positive samples & 10 & 100 & 10 & 100 & 20 & 100 \\
\hline
\end{tabular}


are open water sources showed greater concentration of Coliforms. This may be explained by the nature of the improved water sources construction satisfactorily protects the water from any external contamination [29]. This is consistent with previous studies which suggest that unprotected water sources have high probability of being contaminated by fecal material carried out by runoff water mainly during rainy season [22, 30]. Globally, the results of this study reveal poor quality of water sources used by the population. Our results are consistent with previous studies carried out in the West Cameroon and similar areas which indicated an alarming lack of safe drinking-water [8, 11-14]. Water samples with a small amount of germs turned pathogenic after $24 \mathrm{~h}$ of incubation. This maximum incubation time does not deviate from the WHO recommendations whose procedures include membrane, filtration followed by incubation of the membranes on selective media at 35$37^{\circ} \mathrm{C}$ and counting of colonies after $24 \mathrm{~h} \mathrm{[2].}$

There is no $\mathrm{pH}$ guide value but an optimum between 6.5 and 9.5. The average water $\mathrm{pH}$ found in this study was 6.5 which correspond to the lower value recommended by WHO [2]. The temperature of the samples varied between 22 and $26^{\circ} \mathrm{C}$. This indicator needs to be monitored to support preventive public health to control measures, as it has been established that outbreaks of waterborne diseases such as cholera are consistent with a rise in temperature during the dry season and the peaks are reached in the rainy season [30]. Monitoring temperature and $\mathrm{pH}$ variations during the seasons could help in the planning and implementation of outbreaks prevention measures.

Microbial and other water constituents can affect the appearance of the water [2]. Most samples were clear (90.91\%), suggesting their good quality and acceptability based of this criterion, but the Total Coliforms analysis have shown another case of figure indicating that changes in the normal appearance of water is not a sufficient signal of the water quality.

\section{Conclusions}

This study revealed the poor microbiological quality of the water sources used by inhabitants of West Cameroon. These poor water sources could be at the origin of waterborne disease outbreaks. Even though qualitative analysis was not performed, the MBS method detected the presence of Coliforms in almost all the water samples collected. It is also important to emphasis that the quantity of Coliforms found in the samples could indicate the presence of disease-causing bacteria such as Vibrio Cholerae. The average distance $(8.7 \mathrm{~m})$ between the water point and the nearest latrine doesn't meet up with WHO recommendations (15-50 m to the nearest latrine), showing groundwater high risk of contamination by faeces infiltration. There is need for the local public health services and rural council to establish local water management committees to help in monitoring and ensure water sources do not represent a risk of waterborne disease outbreak. In addition, local populations need to be trained on simple and costeffective of water treatment techniques. Additional qualitative microbiology studies need to be conducted to isolate germs involved in diarrheal diseases.

\section{Abbreviations \\ HACCP: Hazard Analysis Critical Control Point; MBS: Micro Biological Survey; WHO: World Health Organization}

\section{Acknowledgements}

The authors express their gratitude to the administrative staff of the Evangelic University of Cameroon.

\section{Authors' contributions}

MBR and SBBA conceived of the study, participated in its design and coordination, data collection and interpretation, and drafted the manuscript. NPPM participated in the data interpretation and manuscript revision. SSM, JBK and CV participated in the design of the study and manuscript revision. All authors read and approved the different study steps and the final manuscript.

\section{Funding}

This study received no funding.

\section{Availability of data and materials}

The datasets used and/or analyzed during the current study are available from the corresponding author on reasonable request.

\section{Ethics approval and consent to participate}

Our manuscript does not report on or involve the use of any animal or human data or tissue, so an ethics approval and consent are not required with reference to Order No. 079/A/MSP/DS of the Minister of Public Health of October 22, 1987 establishing and organizing an Ethics Committee on Research Involving Human Beings (article 2).

\section{Consent for publication}

Not applicable.

\section{Competing interests}

The authors declare that they have no competing interests.

\section{Author details}

${ }^{1}$ Faculty of Medicine and surgery, University of Roma "Tor Vergata", Rome, Italy. ${ }^{2}$ Institute for Research, Socio-Economic Development and Communication (IRESCO), Yaoundé, Cameroon. ${ }^{3}$ Faculty of Medicine and pharmaceutical Sciences, University of Dschang, Dschang, Cameroon.

${ }^{4}$ Evangelic University of Cameroon, Mboua-Bandjoun, Cameroon.

Received: 7 May 2019 Accepted: 2 March 2020

Published online: 17 March 2020

\section{References}

1. Mohammad ZH. Water: the most precious resource of our life. GJAR. 2015;9: $1436-45$.

2. World Health Organization: Guidelines for drinking-water quality, fourth edition. https://apps.who.int/iris/bitstream/handle/10665/44584/978924154 8151_eng.pdf;jsessionid=71CE4C75E00F2C514911C67F8494A789? sequence= 1 (2011). Accessed on November 21, 2019.

3. Arnold BF, Colford JM Jr. Treating water with chlorine at point-of-use to improve water quality and reduce child diarrhea in developing countries: a systematic review and meta-analysis. Am J Trop Med Hyg. 2007;76:354-64.

4. United Nations: Transforming our world: The 2030 agenda for Sustainable development. A/RES/70/1. https://un.org/ga/search/view doc.asp?symbol= A/RES/70/1\&Lang=E (2015). Accessed on November 21, 2019. 
5. Abdullahi BM, Abdulrahman AS. Water supply and distribution problems in developing countries: a case study of Jimeta-Yola, Nigeria. IJSEAS. 2015;4: 2395-3470.

6. Manish K, Gurmeet S, Tushara C, Pham VQ, Keisuke K. Emerging Water Quality Problems in Developing Countries. Sci World J. 2014. https://doi.org/ 10.1155/2014/215848.

7. Gadgil A. Drinking water in developing countries. Annu Rev Energy Environ. 1998;1:253-86.

8. Mpakam HG, Kamgang K, BV, Kouam K, GR, Tamo T, Georges EE. L'accès à l'eau potable et à l'assainissement dans les villes des pays en développement: cas de Bafoussam (Cameroun). VertigO - la revue électronique en sciences de l'environnement. 2006. https://doi.org/10.4000/ vertigo. 2377 .

9. Hilaire Kouomegne Noubissi. Décentralisation et centralisation au Cameroun. La répartition des compétences entre l'État et les collectivités locales. 1st éd. Paris: L'Harmattan; 2013.

10. Hilaire N, Edmond ND, François K. Analyse des déterminants de l'offre de I'eau potable au Cameroun. HAL. 2017. https://hal.archives-ouvertes.fr/hal01510111. Accessed on November 21, 2019.

11. Wethe J, Radoux M, Tanawa E. Assainissement des eaux usées et risques socio sanitaires et environnementaux en zone d'habitats planifiés de Yaoundé (Cameroun). VerdigO - la revue en Sciences de l'Environnement. 2003;1:12

12. Moussa D, Thomas N, Song L, Daniel EM, Bouba G, HZT S, Moïse N. Bacteriological Quality of Well Waters in Garoua, North Cameroon. Water Qual Expo Health. 2014;6:161.

13. Epule TE, Changhui P, Moto WM, Ndiva MM. Well water quality and public health implications: the case of four neighborhoods of the City of Douala Cameroon. GJHS. 2011;2:75-83.

14. Yongsi HB. Suffering for water, suffering from water: access to drinking water and Associated Health Risks in Cameroon. J Health Popul Nutr. 2010; 5:424-35.

15. Institut National de la Statistique, Ministère de l'Économie de la Planification et de l'Aménagement du Territoire, Ministère de la Santé Publique: Enquête Démographique et de Santé et à Indicateurs Multiples (EDS-MICS) 2011. http://www.measuredhs.com/pubs/pdf/FR260/FR260.pdf (2012). Accessed on November 21, 2019.

16. World Health Organization: Guidelines for Drinking Water Quality. https:// www.who.int/water_sanitation_health/dwq/fulltext.pdf (2008). Accessed on November 21, 2019.

17. Bain R, Cronk R, Wright J, Yang H, Slaymaker T, Bartram J. Fecal Contamination of Drinking-Water in Low- and Middle-Income Countries: A Systematic Review and Meta-Analysis. PLoS Med. 2014. https://doi.org/10. 1371/journal.pmed.1001644.

18. Nicholson K, Neumann K, Dowling C, Sharma S. E. coli and Coliform Bacteria as Indicators for Drinking Water Quality and Handling of Drinking Water in the Sagarmatha National Park, Nepal. EMSD. 2017;2:411-28.

19. Australian government, National health and research council: Recommendations to change the use of coliforms as microbial indicators of drinking water quality. https://www.researchgate.net/publication/31341 9993_Review_of_coliforms_as_microbial_indicators_of_drinking_water_ quality (2003). Accessed on November 21, 2019.

20. Micro Biological Survey. MBS-HACCP\&WATER Easy test: the lab in a vial. https://www.emmebiesse.net/en/igiene-alimentare-haccp/ (2019). Accessed on November 21, 2019.

21. Bureau Central des Recensements et des Etudes de Population - Ministère de l'Economie, de la Planification et de l'Aménagement du Territoire: Cameroun- Recensement Général de la Population et de l'Habitat (2005). http://nada.stat.cm/index.php (2011). Accessed on November 21, 2019.

22. Mendelsohn J, Dawson T. Climate and cholera in kwaZulu-Natal, South Africa: the role of environmental factors and implications for epidemic preparedness. Int J Hyg Environ Health. 2008;211:156-62.

23. Mintz ED, Guerrant RL. A lion in our village - the unconscionable tragedy of cholera in Africa. N Engl J Med. 2009;11:1060-3.

24. Ashbolt NJ, Grabow W, Snozzi M. Indicators of microbial water quality. In: Fewtrell L, Bartham J, editors. WHO Water Series. Water quality-Guidelines, Standards and Health: Assessment of risk and risk management for waterrelated infectious disease. London: IWA Publishing; 2001. p. 289-315.

25. Mengel MA, Delrieu I, Heyerdahl L, Gessner BD. Cholera Outbreaks in Africa. Curr Topics Microbiol Immunol. 2014. https://doi.org/10.1007/82_2014_369.
26. Akoachere TK, Oben MP, Mbivnjo SB, Ndip ML, Nkwelang G, Ndip RN. Bacterial indicators of pollution of the Douala lagoon, Cameroon: public health implications. Afr Health Sci. 2008;2:85-9.

27. Tilley $E$, Ulrich $L$, Lüthi $C$, Reymond $P$, Zurbrügg $C$. Compendium des Systèmes et Technologies d'Assainissement. $1^{\text {st }}$ edition. Dübendorf: Swiss Federal Institute of Aquatic Science and Technology; 2014.

28. United Nations Children's Fund (UNICEF) and World Health Organization: Progress on household drinking water, sanitation and hygiene 2000-2017. Special focus on inequalities. https://www.who.int/water_sanitation_health/ publications/jmp-2019-full-report.pdf?ua=1 (2019). Accessed on November 21, 2019.

29. Singh RB, Hales S, De Wet N, Heamden M, Weinstein P. The influence of climate variation and change on diarrheal diseases in the Pacific Island. Environ Health Perspect. 2001;2:155-9.

30. Fernandez MAL, Bauernfeind A, Jiménezn JD, Gli CL, Omeiri NE, Guibert DH. Influence of temperature and rainfall on the evolution of cholera epidemics in Lusaka, Zambia, 2003-2006; analysis of a time series. Trans R Soc Trop Med Hyg. 2009;2:137-43.

\section{Publisher's Note}

Springer Nature remains neutral with regard to jurisdictional claims in published maps and institutional affiliations.
Ready to submit your research? Choose BMC and benefit from:

- fast, convenient online submission

- thorough peer review by experienced researchers in your field

- rapid publication on acceptance

- support for research data, including large and complex data types

- gold Open Access which fosters wider collaboration and increased citations

- maximum visibility for your research: over $100 \mathrm{M}$ website views per year

At BMC, research is always in progress.

Learn more biomedcentral.com/submissions 